\title{
Implementasi Metode Topsis Pada Sistem Pendukung Keputusan Penerima KKS Pada Desa Tawang
}

\author{
Tuti Alawiyah', Tina Supriatin², Herlan Sutisna3 ${ }^{3}$ Agung Baitul Hikmah, Bambang Kelana \\ Simpony ${ }^{5}$
}

\begin{abstract}
1,2,3,4,5Prodi Sistem Informasi Kampus Kota Tasikmalaya, Universitas Bina Sarana Informatika
1'tuti.tah@bsi.ac.id, 2tinaalahsani@gmail.com, ${ }^{3}$ herlan.her@bsi.ac.id, ${ }^{4}$ agung.abl@bsi.ac.id,

5bambang.bky@bsi.ac.id
\end{abstract}

\begin{abstract}
Kartu Keluarga Sejahtera (KKS) is one of the government's programs to accelerate poverty reduction as stated in Presidential Regulation (Perpres) number 166 of 2014. Kartu Keluarga Sejahtera (KKS) functions as a marker for underprivileged people and also as an identity card to get the Prosperous Family Savings Program. However, sometimes KKS assistance is not on target. This is because the assessment of prospective recipients of KKS assistance is subjective and the selection process is quite slow. This resea

rch was conducted with the aim of designing a web-based decision support information system using the TOPSIS (Technique For Order Of Preference by Similarity To Ideal) method in the process of selecting prospective recipients of KKS assistance. The result of this research is an information system that can produce a sequence of KKS aid recipients as a consideration in determining the recipients of KKS assistance. With this information system, data processing can be done quickly, accurately and the process of assessing potential recipients of KKS assistance becomes more objective.
\end{abstract}

Keywords: Topsis Method, Decision Support System, KKS

\begin{abstract}
Abstrak: Kartu Keluarga Sejahtera (KKS) merupakan salah satu program pemerintah dalam percepatan penanggulangan kemiskinan yang tercantum dalam Peraturan Presiden (Perpres) nomor 166 tahun 2014. Kartu Keluarga Sejahtera (KKS) berfungsi sebagai penanda masyarakat kurang mampu dan juga sebagai kartu identitas untuk mendapatkan Program Simpan Keluarga Sejahtera. Namun terkadang bantuan KKS kurang tepat sasaran. Hal ini disebabkan karena penilaian calon penerima bantuan Kartu Keluarga Sejahtera (KKS) bersifat subjektif serta proses penyeleksian berjalan cukup lambat. Penelitian ini dilakukan dengan tujuan untuk merancang sistem informasi pendukung keputusan berbasis web dengan menggunakan metode TOPSIS (Technique For Order Of Preference by Similarity To Ideal) pada proses penyeleksian calon penerima bantuan KKS. Hasil dari penelitian ini adalah sebuah sistem informasi yang dapat menghasilkan urutan calon penerima bantuan KKS sebagai bahan pertimbangan dalam menentukan penerima bantuan KKS. Dengan adanya sistem informasi ini, pengolahan data dapat dilakukan secara cepat, tepat dan proses penilaian calon penerima bantuan KKS menjadi lebih objektif.
\end{abstract}

Kata kunci: Metode Topsis, Sistem Pendukung Keputusan, KKS

\section{A. PENDAHULUAN}

Kartu Keluarga Sejahtera (KKS) merupakan salah satu program pemerintah dalam percepatan penanggulangan kemiskinan yang tercantum pada Peraturan Presiden (Perpres) nomor 166 Tahun 2014 tentang penanggulangan kemiskinan. Selain sebagai penanda masyarakat kurang mampu, KKS juga berfungsi sebagai kartu identitas untuk mendapatkan Program Simpanan Keluarga Sejahtera (PSKS). Berdasarkan Basis Data Terpadu (BDT) yang diolah oleh Tim Nasional Percepatan Penanggulangan Kemiskinan (TNP2KP), penerima 
bantuan KKS sebanyak 25\% dari total jumlah penduduk yang ada dengan status sosial ekonomi terendah dengan jumlah kisaran bantuan yang diberikan sebesar Rp.200.000/keluarga/perbulan.

Permasalahan yang sering muncul adalah ketidaktepatan pada data RTS (rumah Tangga Sasaran). Hal ini disebabkan data yang diberikan dari pusat adalah data dari tahun 2010. Data yang tidak valid, menyebabkan kesalahan dalam pembagian KKS yang seharusnya diberikan kepada keluarga yang berhak menerimanya. Beberapa warga miskin yang tidak mendapatkan KKS mengeluhkan kejadian ini, karena mereka seharusnya masuk dalam daftar RTS (Rumah Tangga Sasaran). Pendataan warga harus dilakukan berulang secara periodik, agar Badan Pusat Statistik (BPS) mendapatkan data yang valid dan terupdate.

Desa Tawang, Kecamatan Pancatengah, Kabupaten Tasikmalaya merupakan salah satu daerah yang masuk dalam program Kartu Keluarga Sejahtera. Namun dalam pelaksanaannya ditemukan permasalahan dalam penentuan rumah tangga penerima KKS diantaranya penilaian yang kurang objektif dan proses penyeleksiannya yang berjalan cukup lambat. Berdasarkan permasalahan ini, diperlukan pendataan ulang dan validasi data oleh aparat desa. Dalam menentukan rumah tangga yang berhak menerima bantuan KKS, diperlukan suatu metode yang terstruktur dan terkomputerisasi agar penyeleksian bersifat objektif. Dalam penelitian ini, metode TOPSIS (Techinique for Order Preference by Similarity to Ideal Solution) akan digunakan untuk menentukan rumah tangga penerima bantuan KKS yang akan menghasilkan data urut (rangking) rumah tangga yang berhak mendapatkan bantuan. Hasil perangkingan ini dapat dijadikan sebagai alternatif dalam pengambilan keputusan pada musyawarah desa.

Metode TOPSIS telah banyak digunakan peneliti dalam sistem pendukung keputusan. (Siahaya \& T. Arie Setiawan P, S.T., 2015) mengimplementasikan metode TOPSIS dalam sistem pendukung keputusan yang digunakan untuk mengevaluasi kinerja guru dengan 3 kriteria yang digunakan yaitu kriteria pra pembelajaran, kriteria kegiatan inti, dan kriteria penutup. (Arifin, 2015) mengimplementasikan metode topsis pada Sistem Pendukung Keputusan Rekomendasi Pemilihan Mobil Bekas dengan kriteria yang digunakan aksesoris interior, kapasitas penumpang, kapasitas mesin, harga, dan kenyamanan.

Dalam proses penerimaan karyawan baru, diperlukan penilaian yang objektif dan pertimbangan yang baik untuk mendapatkan karyawan yang tepat dan sesuai dengan kebutuhan perusahaan. (Hertyana, 2019) menggunakan metode TOPSIS untuk menyeleksi calon karyawan baru dengan kriteria yang digunakan terdiri dari pendidikan, pengalaman kerja, skill/kemampuan, usia, dan karakter. Sedangkan (Suryadi, 2017) mengimplementasikan metode topsis dalam penerimaan karyawan menggunakan kriteria nilai akademik (IPK/UAN), kompetensi (kemampuan/pengalaman), hasil psikotes, dan hasil wawancara dengan bobot $30 \%$ untuk kriteria nilai akademik (IPK/UAN), 25\% untuk kriteria kompetensi (kemampuan/pengalaman), 20\% untuk kriteria hasil psikotes, dan 25\% untuk kriteria hasil wawancara.

Penentuan keputusan dalam pemberian kredit memerlukan pertimbangan yang baik untuk memastikan penerima kredit dapat mengembalikan pinjamannya tepat waktu. Mubarok, Suherman, Ramdhani, \& Topiq, 2019 mengimplementasikan metode TOPSIS untuk membantu dalam menentukan anggota koperasi syariah BMT itQan yang berhak mendapatkan pinjaman dengan kriteria yang digunakan meliputi penilaian indeks rumah, penilaian ppi skor, penilaian repaymen cap, penilain kebutuhan pembiayaan, dan penilaian pendapatan.

\section{B. TINJAUAN PUSTAKA}

Peraturan Menteri Sosial RI Nomor 1 Tahun 2018 (Pasal 1 ayat 10) Tentang Program Keluarga Harapan menjelaskan bahwa: "Kartu Keluarga Sejahtera adalah Kartu Kombo yang digunakan sebagai media penyaluran Bantuan Sosial PKH secara nontunai".

Kartu Keluarga Sejahtera (KKS) merupakan salah satu sarana dari pemerintah untuk menyalurkan bantuan sosial dan subsidi yang menjadi karya inovatif pertamakali yang digunakan diantara banyak negara yang melakukan Bantuan Tunai Bersyarat (Conditional Cash Transfer). KKS mempunya fungsi sebagai tabungan juga sebagai dompet (e-wallet) (Hikmat, 2017).

KKS sebagai tabungan mempunyai fitur antara lain:

1. Tabungan adalah Simpanan berupa Rekening Bank yang dapat ditarik secara tunai. 
2. Produk TabunganKU - Lakupandai.

3. Mendukung program Keuangan Inklusif.

4. Wadah menyalurkan bantuan sosial PKH dan bantuan tabungan lainnya.

KKS sebagai e-wallet mempunyai fitur antara lain:

1. e-Wallet adalah Simpanan uang elektronik.

2. Dapat digunakan belanja barang/tidak bisa di tarik tunai.

3. Kuota Barang.

4. Wadah menyalurkan Bantuan Pangan Non Tunai, Bantuan LPG $3 \mathrm{Kg}$, dan bantuan barang lainnya.

TOPSIS (Technique For Order Of Preference by Similarity to Ideal Solution) merupakan salah satu metode yang banyak digunakan dalam pengambilan keputusan multikriteria yang diperkenalkan tahun 1981 oleh Yoon dan Hwang.alternatif. Alternatif yang terpilih harus mempunya jarak terdekat dari solusi ideal positif dan jarak terjauh dari solusi ideal negatif. Untuk menentukan kedekatan relatif dari suatu alternatif berdasarkan sudut pandang geometris dengan menggunakan jarak Euclidean. (Nofriansyah, 2015).

\section{METODE PENELITIAN}

Algoritma metode TOPSIS:

1. Menentukan normalisasi matriks keputusan.

$r_{i j}=\frac{x_{i j}}{\sqrt{\sum_{i=1}^{m} x_{i j}^{2}}}$

Tabel 1. Bobot Kriteria

\begin{tabular}{|l|l|}
\hline Kriteria & Bobot \\
\hline C1 = Jumlah Tanggungan Kepala Rumah Tangga & $25 \%$ \\
\hline C2 = Rata-rata Penghasilan Kepala Keluarga & $25 \%$ \\
\hline C3 = Pendidikan Tertinggi Kepala Rumah Tangga & $15 \%$ \\
\hline C4 = Kondisi Bangunan Rumah & $15 \%$ \\
\hline C5 = Status Rumah Yang di tempati & $10 \%$ \\
\hline C6 = Jenis Lantai Rumah & $10 \%$ \\
\hline
\end{tabular}

Sumber : (Yuliawati, 2017)

Tabel 2. Kategori Penilaian Perhitungan

\begin{tabular}{|l|l|}
\hline Penilaian Perhitungan & Nilai \\
\hline Tidak Layak $(\mathrm{TL})$ & 0 \\
\hline Kurang Layak $(\mathrm{KL})$ & 0,25 \\
\hline Cukup Layak $(\mathrm{CK})$ & 0,50 \\
\hline Layak (L) & 0,75 \\
\hline Sangat Layak $(\mathrm{SL})$ & 1 \\
\hline
\end{tabular}

Sumber : (Yuliawati, 2017)

Tabel 3. Nilai Sub Kriteria Jumlah Tanggungan Kepala Rumah Tangga (C1)

\begin{tabular}{|l|l|}
\hline Jumlah Tanggungan & Nilai \\
\hline 1 & 0 \\
\hline 2 & 0,25 \\
\hline 3 & 0,50 \\
\hline 4 & 0,75 \\
\hline$>5$ & 1 \\
\hline
\end{tabular}

Sumber : (Yuliawati, 2017) 
Tabel 4. Nilai Sub Kriteria Rata-rata Penghasilan Kepala Keluarga (C2)

\begin{tabular}{|l|l|}
\hline Pendapatan Rumah Tangga Dalam 1 Bulan & Nilai \\
\hline Rp. 500.000 & 1 \\
\hline Rp. 500.001 - Rp. 1.000 .000 & 0,75 \\
\hline Rp. $1.000 .001-$ Rp. 2.000 .000 & 0,50 \\
\hline Rp. 2.000.001 - Rp. 3.500.000 & 0,25 \\
\hline > Rp. 3.500.000 & 0 \\
\hline
\end{tabular}

Sumber : (Yuliawati, 2017)

Tabel 5. Nilai Sub Kriteria Pendidikan Tertinggi Kepala keluarga (C3)

\begin{tabular}{|l|l|}
\hline Pendidikan Tertinggi & Nilai \\
\hline Tidak Sekolah & 1 \\
\hline SD/MI/Sederajat & 0,75 \\
\hline SMP/MTS/Sederajat & 0,50 \\
\hline SMA/MAN/SMK/Sederajat & 0,25 \\
\hline Perguruan Tinggi & 0 \\
\hline
\end{tabular}

Sumber : (Yuliawati, 2017)

Tabel 6. Nilai Sub Kriteria Kondisi Bangunan Rumah (C4)

\begin{tabular}{|l|l|}
\hline Kondisi Bangunan Rumah & Nilai \\
\hline Tidak Tetap/Menumpang & 1 \\
\hline Non Permanen & 0,75 \\
\hline Semi Permanen & 0,25 \\
\hline Permanen & 0 \\
\hline
\end{tabular}

Sumber : (Yuliawati, 2017)

Tabel 7. Nilai Sub Kriteria Status Rumah Yang ditempati (C5)

\begin{tabular}{|l|l|}
\hline Status Rumah yang di tempati & Nilai \\
\hline Milik Sendiri & 0,50 \\
\hline Kontrak/Sewa & 1 \\
\hline Bebas Sewa & 0,75 \\
\hline Dinas & 0 \\
\hline Dan Lainnya & 0,25 \\
\hline
\end{tabular}

Sumber :(Yuliawati, 2017)

Tabel 8. Nilai Sub Kriteria Jenis Lantai Rumah (C6)

\begin{tabular}{|c|c|}
\hline Jenis Lantai & Nilai \\
\hline Marmer/Granit & 0 \\
\hline Keramik & 0,25 \\
\hline Semen & 0,50 \\
\hline Bambu/Papan & 0,75 \\
\hline Tanah & 1 \\
\hline
\end{tabular}

2. Menetukan bobot ternormalisasi matriks keputusan.

$y_{i j}=w_{i j} r_{i j}$;

$A^{+}=\left(y_{1}^{+}, y_{2}^{+}, \ldots, y_{n}^{+}\right)$;

$A^{-}=\left(y_{1}^{-}, y_{2}^{-}, \ldots . . y_{n}^{-}\right)$;

$y_{j}^{+}=\left\{\begin{array}{l}\max y_{i j} ; j i k a j \text { adalah atribut keuntungan } \\ \max y_{i j} ; j i k a j \text { adalah atribut biaya }\end{array}\right\}$ 
$y_{1}^{-}=\left\{\begin{array}{l}\max y_{i j} ; j i k a j \text { adalah atribut keuntungan } i \\ \max y_{i j} ; j i k a j \text { adalah atribut biaya } i\end{array}\right\}$

3. Jarak antara alternatif $A i$ dengan solusi ideal positif di rumuskan sebagai:

$D_{i}^{+}=\sqrt{\sum_{j=1}^{n}}\left(y_{i}^{+}-y_{i j}\right)^{2}$;

Jarak antara alternatif $A_{i}$ dengan solusi ideal negatif dirumuskan sebagai :

$$
D_{i}^{-}=\sqrt{\sum_{j=1}^{n}}\left(y_{i j}-y_{i}^{-}\right)^{2} ;
$$

4. Nilai prefensi untuk setiap alternatif $\left(\mathrm{V}_{\mathrm{i}}\right)$ diberikan sebagai:

$$
v_{i}=\frac{D_{i}^{-}}{D_{i}^{-}+D_{i}^{+}} ; \quad i=1,2, \ldots . ., m .
$$

Nilai $V_{i}$ yang lebih besar menunjukan bahwa alternatif $A_{i}$ lebih dipilih.

\section{HASIL DAN PEMBAHASAN}

\section{Analisa Kebutuhan}

Dalam rancangan sistem pendukung keputusan penerima Kartu Keluarga Sejahtera (KKS) terdapat dua pengguna yaitu admin dan kepala desa.

1. Skenario Kebutuhan Admin

a. Admin dapat melakukan login.

b. Admin dapat melakukan input, dan edit data calon penerima KKS.

c. Admin dapat melihat kriteria dan sub kriteria.

d. Admin dapat memulai proses perhitungan.

e. Admin dapat melihat hasil perhitungan metode topsis

f. Admin dapat mencetak laporan sesuai kebutuhan.

2. Skenaroio Kebutuhan Kepala Desa

a. Kepala Desa dapat melihat data calon penerima KKS.

b. Kepala Desa dapat melakukan edit data calon penerima KKS.

c. Kepala Desa dapat mencetak laporan sesuai kebutuhan.

3. Kebutuhan Sistem

a. Sistem mampu mengelola data keluarga.

b. Sistem mampu menampilkan data kriteria dan sub kriteria.

c. Sistem dapat menyeleksi calon penerima Kartu Keluarga Sejahtera menggunakan metode Topsis.

d. Sistem mampu mengelola laporan hasil seleksi calon penerima Kartu Keluarga Sejahtera.

\section{Perhitungan Topsis}

Pada tahap ini di bangun sistem pendukung keputusan penentuan penerima Kartu Keluarga Sejahtera pada Desa Tawang dengan menggunakan metode Topsis. Pada tahap ini dilakukan pengujian sistem, yaitu menjalankan proses implementasi sistem, dengan menguji hasil akhir perhitungan Topsis pada sistem dengan perhitungan manual yang dilakukan oleh user.

\begin{tabular}{|c|c|c|c|c|c|c|}
\hline Alternatif & \multicolumn{6}{|c|}{ Kriteria } \\
\hline RTS & C1 & $\mathrm{C} 2$ & C3 & C4 & C5 & C6 \\
\hline Rendi & 2 & $\operatorname{Rp} 800.000$ & Tidak Sekolah & Semi Permanen & Milik Sendiri & semen \\
\hline Anwar & 4 & Rp 3.000.000 & SMP & Permanen & Kontrak/Sewa & Keramik \\
\hline Ipan & 4 & Rp 1.000 .000 & SD & Permanen & Milik Sendiri & Keramik \\
\hline Unang & 3 & $R p 2.500 .000$ & SMA & Semi Permanen & Bebas Sewa & semen \\
\hline Deni & 2 & Rp.3.500.000 & Perguruan & Permanen & Milik Sendiri & Keramik \\
\hline
\end{tabular}

Tabel 9. Data Rumah Tangga Sasaran (RTS) 
IJSE - Indonesian Journal on Software Engineering, Vol.6, No.2, Desember 2020, 152-162

\begin{tabular}{|c|c|c|c|c|c|c|}
\hline & & & Tinggi & & & \\
\hline Mustopa & 2 & Rp 900.000 & SD & Non Permanen & Milik Sendiri & Papan \\
\hline Nunung & 1 & Rp 3.000.000 & SD & Semi Permanen & Milik Sendiri & semen \\
\hline Ade & 4 & $\operatorname{Rp} 600.000$ & Tidak Sekolah & Menumpang & Bebas Sewa & Keramik \\
\hline Agus & 3 & Rp 1.000 .000 & SMP & Semi Permanen & Milik Sendiri & Keramik \\
\hline ljam & 2 & Rp 2.000.000 & SD & Permanen & Milik Sendiri & Keramik \\
\hline Rudi & 3 & Rp 1.000 .000 & SMA & Non Permanen & Milik Sendiri & Tanah \\
\hline Agung & 3 & Rp 4.000.000 & $\begin{array}{l}\text { Perguruan } \\
\text { Tinggi }\end{array}$ & Permanen & Milik Sendiri & Granit \\
\hline Ma,mun & 5 & $\operatorname{Rp} 900.000$ & SD & Permanen & Milik Sendiri & Keramik \\
\hline Itang & 2 & Rp 5.000.000 & SD & Permanen & Milik Sendiri & Keramik \\
\hline Aceng & 1 & Rp 1.800.000 & SMA & Permanen & Milik Sendiri & Keramik \\
\hline Engkos & 1 & Rp 800.000 & Tidak Sekolah & semi Perma & Milik Sendiri & Keramik \\
\hline Iwan & 3 & Rp 6.000.000 & $\begin{array}{l}\text { Perguruan } \\
\text { Tinggi }\end{array}$ & Permanen & Milik Sendiri & Keramik \\
\hline Muslimin & 4 & Rp 2.600 .000 & Tidak Sekolah & Permanen & Milik Sendiri & Keramik \\
\hline $\begin{array}{l}\text { Agus } \\
\text { Epul }\end{array}$ & 2 & $\operatorname{Rp} 4.500 .000$ & $\begin{array}{l}\text { Perguruan } \\
\text { Tinggi }\end{array}$ & Permanen & Milik Sendiri & Keramik \\
\hline Ade & 2 & Rp 2.000.000 & SMP & Semi Permanen & Milik Sendiri & Keramik \\
\hline Jaja & 2 & Rp 2.100.000 & SD & Menumpang & Bebas Sewa & semen \\
\hline Adang & 2 & Rp 3.600.000 & SMP & Permanen & Milik Sendiri & Keramik \\
\hline Nano & 3 & Rp 1.500 .000 & SD & Menumpang & Bebas Sewa & semen \\
\hline Atep & 3 & Rp 3.000.000 & SMA & Permanen & Milik Sendiri & keramik \\
\hline Dodi & 2 & $R p 1.800 .000$ & SD & Sem & endiri & eram \\
\hline
\end{tabular}

Tabel 10. Matriks Penilaian

\begin{tabular}{|l|l|l|l|l|l|l|}
\hline Alternatif & C1 & C2 & C3 & C4 & C5 & C6 \\
\hline A1 & 0,25 & 0,75 & 1 & 0,25 & 0,50 & 0,50 \\
\hline A2 & 0,75 & 0,25 & 0,50 & 0 & 1 & 0,25 \\
\hline A3 & 0,75 & 0,75 & 0,75 & 0 & 0,50 & 0,25 \\
\hline A4 & 0,50 & 0,25 & 0,25 & 0,25 & 0,75 & 0,50 \\
\hline A5 & 0,25 & 0 & 0 & 0 & 0,50 & 0,25 \\
\hline A6 & 0,25 & 0,75 & 0,75 & 0,75 & 0,50 & 0,75 \\
\hline A7 & 0 & 0,25 & 0,75 & 0,25 & 0,50 & 0,50 \\
\hline A8 & 0,75 & 0,75 & 1 & 1 & 0,75 & 0,25 \\
\hline A9 & 0,50 & 0,75 & 0,50 & 0,25 & 0,50 & 0,25 \\
\hline A10 & 0,25 & 0,50 & 0,75 & 0 & 0,50 & 0,25 \\
\hline A11 & 0,50 & 0,75 & 0,25 & 0,75 & 0,50 & 1 \\
\hline A12 & 0,50 & 0 & 0 & 0 & 0,50 & 0 \\
\hline A13 & 1 & 0,75 & 0,75 & 0 & 0,50 & 0,25 \\
\hline A14 & 0,25 & 0 & 0,75 & 0 & 0,50 & 0,25 \\
\hline A15 & 0 & 0,50 & 0,25 & 0 & 0,50 & 0,25 \\
\hline A16 & 0 & 0,75 & 1 & 0,25 & 0,50 & 0,25 \\
\hline A17 & 0,50 & 0 & 0 & 0 & 0,50 & 0,25 \\
\hline A18 & 0,75 & 0,25 & 1 & 0 & 0,50 & 0,25 \\
\hline A19 & 0,25 & 0 & 0 & 0 & 0,50 & 0,25 \\
\hline A20 & 0,25 & 0,50 & 0,50 & 0,25 & 0,50 & 0,25 \\
\hline A21 & 0,25 & 0,25 & 0,75 & 1 & 0,75 & 0,50 \\
\hline A22 & 0,25 & 0 & 0,50 & 0 & 0,50 & 0,25 \\
\hline A23 & 0,50 & 0,50 & 0,75 & 1 & 0,75 & 0,50 \\
\hline A24 & 0,50 & 0,25 & 0,25 & 0 & 0,50 & 0,25 \\
\hline A25 & 0,25 & 0,50 & 0,75 & 0,25 & 0,50 & 0,25 \\
\hline Xij & 2,37 & 2,47 & 3,21 & 2,14 & 2,87 & 1,97 \\
\hline
\end{tabular}


$X_{i j}$ adalah jumlah nilai kriteria dari tiap alternatif (RTS), untuk menentukan nilai nya yaitu dengan cara menjumlahkan kuadrat semua nilai penilaian masing-masing kriteria. Langkah berikutnya adalah membuat matriks keputusan ternormalisasi dengan cara membagi nilai penilaian pada masing-masing alternatif (RTS) per kriteria pada tabel 11 dengan nilai $X_{i j}$ per kriteria.

$$
\begin{aligned}
& r_{i j}=\frac{x_{i j}}{\sqrt{\sum_{i=1}^{m} x_{i j}^{2}}} \\
& X_{i j}\left(C_{1}\right)=\sqrt{(0,25)^{2}+(0,75)^{2}+(0,75)^{2}+(0,50)^{2}+(0,25)^{2}+} \begin{array}{c}
(0,25)^{2}+(0)^{2}+(0,75)^{2}+(0,50)^{2}+(0,25)^{2}+ \\
(0,50)^{2}+(0,50)^{2}+(1)^{2}+(0,25)^{2}+(0)^{2}+ \\
(0)^{2}+(0,50)^{2}+(0,75)^{2}+(0,25)^{2}+(0,25)^{2}+ \\
(0,25)^{2}+(0,25)^{2}+(0,50)^{2}+(0,50)^{2}+(0,25)^{2}=2,37
\end{array}
\end{aligned}
$$
$A_{1}=\frac{0,25}{2,97}=0,11$
$A_{6}=\frac{0,25}{2.97}=0,11$
$A_{11}=\frac{0,50}{2,97}=0,21$
$A_{16}=\frac{0}{2.97}=0$
$A_{21}=\frac{0,25}{2,97}=0,11$
$A_{2}=\frac{0,75}{2, a 7}=0,31$
$A_{7}=\frac{0}{297}=0$
$A_{12}=\frac{0,50}{2,97}=0,21$
$A_{17}=\frac{0,50}{2,97}=0,21$
$A_{22}=\frac{0,25}{2,297}=0,11$
$A_{3}=\frac{0,75}{2.977}=0,32$
$A_{8}=\frac{0,75}{2297}=0,32$
$A_{13}=\frac{1}{2, a 7}=0,42$
$A_{18}=\frac{0,75}{2297}=0,32$
$A_{23}=\frac{0,50}{2,97}=0,21$
$A_{4}=\frac{0,50}{2, a 7}=0,21$
$A_{9}=\frac{0,50}{2.97}=0,21$
$A_{14}=\frac{0,25}{2,97}=0,11$
$A_{19}=\frac{0,25}{2,97}=0,11$
$A_{24}=\frac{0,50}{2,297}=0,21$
$A_{5}=\frac{0,25}{2,297}=0,11$
$A_{10}=\frac{0,25}{2297}=0,11$
$A_{15}=\frac{0}{2 a 7}=0$
$A_{20}=\frac{0,25}{2,97}=0,11$
$A_{25}=\frac{0,25}{2297}=0,11$

Tabel 11. Matriks Keputusan Ternormalisasi

\begin{tabular}{|l|l|l|l|l|l|l|}
\hline Alternatif & C1 & C2 & C3 & C4 & C5 & C6 \\
\hline A1 & 0,11 & 0,30 & 0,31 & 0,12 & 0,17 & 0,25 \\
\hline A2 & 0,32 & 0,10 & 0,16 & 0 & 0,35 & 0,13 \\
\hline A3 & 0,32 & 0,30 & 0,23 & 0 & 0,17 & 0,13 \\
\hline A4 & 0,21 & 0,10 & 0,08 & 0,12 & 0,26 & 0,25 \\
\hline A5 & 0,11 & 0 & 0 & 0 & 0,17 & 0,13 \\
\hline A6 & 0,11 & 0,30 & 0,23 & 0,35 & 0,17 & 0,38 \\
\hline A7 & 0 & 0,10 & 0,23 & 0,12 & 0,17 & 0,25 \\
\hline A8 & 0,32 & 0,30 & 0,31 & 0,47 & 0,26 & 0,13 \\
\hline A9 & 0,21 & 0,30 & 0,16 & 0,12 & 0,17 & 0,13 \\
\hline A10 & 0,11 & 0,20 & 0,23 & 0 & 0,17 & 0,13 \\
\hline A11 & 0,21 & 0,30 & 0,08 & 0,35 & 0,17 & 0,51 \\
\hline A12 & 0,21 & 0,00 & 0 & 0 & 0,17 & 0 \\
\hline A13 & 0,42 & 0,30 & 0,23 & 0 & 0,17 & 0,13 \\
\hline A14 & 0,11 & 0 & 0,23 & 0 & 0,17 & 0,13 \\
\hline A15 & 0 & 0,20 & 0,08 & 0 & 0,17 & 0,13 \\
\hline A16 & 0 & 0,30 & 0,31 & 0,12 & 0,17 & 0,13 \\
\hline A17 & 0,21 & 0,00 & 0 & 0 & 0,17 & 0,13 \\
\hline A18 & 0,32 & 0,10 & 0,31 & 0 & 0,17 & 0,13 \\
\hline A19 & 0,11 & 0 & 0,00 & 0 & 0,17 & 0,13 \\
\hline A20 & 0,11 & 0,20 & 0,16 & 0,12 & 0,17 & 0,13 \\
\hline A21 & 0,11 & 0,10 & 0,23 & 0,47 & 0,26 & 0,25 \\
\hline A22 & 0,11 & 0 & 0,16 & 0,00 & 0,17 & 0,13 \\
\hline A23 & 0,21 & 0,20 & 0,23 & 0,47 & 0,26 & 0,25 \\
\hline A24 & 0,21 & 0,10 & 0,08 & 0 & 0,17 & 0,13 \\
\hline A25 & 0,11 & 0,20 & 0,23 & 0,12 & 0,17 & 0,13 \\
\hline & & & & & & \\
\hline
\end{tabular}


IJSE - Indonesian Journal on Software Engineering, Vol.6, No.2, Desember 2020, 152-162 pISSN: 2461-0690 I elSSN: 2714-9935

Langkah selanjutnya adalah mencari nilai $Y_{i j}$ dengan cara melakukan perkalian antara nilai $R_{i j}$ dengan nilai bobot. Dan mencari nilai $Y \max$ (solusi ideal positif) dan $Y$ min (solusi ideal negatif).

Bobot $\mathrm{C} 1=25 \%$

$A_{1}=0,25 * 0,11=0,03$

$A_{2}=0,25 * 0,32=0,08$

$A_{3}=0,25 * 0,32=0,08$

$A_{4}=0,25 * 0,21=0,05$

$A_{5}=0,25 * 0,11=0,03$

$A_{6}=0,25 * 0,11=0,03$

$A_{7}=0,25 * 0=0,0$

$A_{8}=0,25 * 0,32=0,08$

$A_{9}=0,25 * 0,21=0,05$

$$
\begin{aligned}
& A_{10}=0,25 * 0,11=0,03 \\
& A_{11}=0,25 * 0,21=0,05 \\
& A_{12}=0,25 * 0,21=0,05 \\
& A_{13}=0,25 * 0,42=0,11 \\
& A_{14}=0,25 * 0,11=0,03 \\
& A_{15}=0,25 * 0=0 \\
& A_{16}=0,25 * 0=0 \\
& A_{17}=0,25 * 0,21=0,05 \\
& A_{18}=0,25 * 0,32=0,08
\end{aligned}
$$

Tabel 12. Matriks Bobot Ternormalisasi

\begin{tabular}{|l|l|l|l|l|l|l|}
\hline & C1 & C2 & C3 & C4 & C5 & C6 \\
\hline Bobot & $25 \%$ & $25 \%$ & $15 \%$ & $15 \%$ & $10 \%$ & $10 \%$ \\
\hline A1 & 0,03 & 0,08 & 0,05 & 0,02 & 0,02 & 0,03 \\
\hline A2 & 0,08 & 0,03 & 0,02 & 0 & 0,03 & 0,01 \\
\hline A3 & 0,08 & 0,08 & 0,04 & 0 & 0,02 & 0,01 \\
\hline A4 & 0,05 & 0,03 & 0,01 & 0,02 & 0,03 & 0,03 \\
\hline A5 & 0,03 & 0 & 0 & 0 & 0,02 & 0,01 \\
\hline A6 & 0,03 & 0,08 & 0,04 & 0,05 & 0,02 & 0,04 \\
\hline A7 & 0 & 0,03 & 0,04 & 0,02 & 0,02 & 0,03 \\
\hline A8 & 0,08 & 0,08 & 0,05 & 0,07 & 0,03 & 0,01 \\
\hline A9 & 0,05 & 0,08 & 0,02 & 0,02 & 0,02 & 0,01 \\
\hline A10 & 0,03 & 0,05 & 0,04 & 0,0 & 0,02 & 0,01 \\
\hline A11 & 0,05 & 0,08 & 0,01 & 0,05 & 0,02 & 0,05 \\
\hline A12 & 0,05 & 0 & 0 & 0 & 0,02 & 0 \\
\hline A13 & 0,11 & 0,08 & 0,04 & 0 & 0,02 & 0,01 \\
\hline A14 & 0,03 & 0 & 0,04 & 0 & 0,02 & 0,01 \\
\hline A15 & 0 & 0,05 & 0,01 & 0 & 0,02 & 0,01 \\
\hline A16 & 0 & 0,08 & 0,05 & 0,02 & 0,02 & 0,01 \\
\hline A17 & 0,05 & 0 & 0,00 & 0 & 0,02 & 0,01 \\
\hline A18 & 0,08 & 0,03 & 0,05 & 0 & 0,02 & 0,01 \\
\hline A19 & 0,03 & 0 & 0 & 0 & 0,02 & 0,01 \\
\hline A20 & 0,03 & 0,05 & 0,02 & 0,02 & 0,02 & 0,01 \\
\hline A21 & 0,03 & 0,03 & 0,04 & 0,07 & 0,03 & 0,03 \\
\hline A22 & 0,03 & 0 & 0,02 & 0 & 0,02 & 0,01 \\
\hline A23 & 0,05 & 0,05 & 0,04 & 0,07 & 0,03 & 0,03 \\
\hline A24 & 0,05 & 0,03 & 0,01 & 0 & 0,02 & 0,01 \\
\hline A25 & 0,03 & 0,05 & 0,04 & 0,02 & 0,02 & 0,01 \\
\hline Ymax & 0,11 & 0,08 & 0,05 & 0,07 & 0,03 & 0,05 \\
\hline Ymin & 0 & 0 & 0 & 0 & 0,02 & 0 \\
\hline & & & & & & \\
\hline
\end{tabular}

Langkah selanjutnya adalah menghitung nilai $D+$ (jarak alternatif solusi ideal positif) dan $D$ (jarak alternatif solusi ideal negatif).

$$
\begin{aligned}
& D_{i}^{+}=\sqrt{\sum_{j=1}^{n}\left(y_{i}^{+}-y_{i j}\right)^{2} ;} \\
& \mathrm{A}_{1}=\sqrt{\begin{array}{c}
(0,11-0,03)^{2}+(0,08-0,08)^{2}+(0,05-0,05)^{2}+(0,07-0,02)^{2} \\
+(0,03-0,02)^{2}+(0,05-0,03)^{2}=0,61
\end{array}}
\end{aligned}
$$




$$
\begin{aligned}
& A_{2}=\begin{array}{c}
\begin{array}{c}
(0,11-0,08)^{2}+(0,08-0,03)^{2}+(0,05-0,02)^{2}+(0,07-0)^{2} \\
+(0,03-0,03)^{2}+(0,05-0,01)^{2}=0,61
\end{array} \\
A_{3}=\sqrt{\begin{array}{c}
(0,11-0,08)^{2}+(0,08-0,08)^{2}+(0,05-0,04)^{2}+(0,07-0)^{2} \\
+(0,03-0,02)^{2}+(0,05-0,01)^{2}=0,61
\end{array}} \\
A_{4}=\sqrt{\begin{array}{c}
(0,11-0,05)^{2}+(0,08-0,03)^{2}+(0,05-0,01)^{2}+(0,07-0,02)^{2} \\
+(0,03-0,03)^{2}+(0,05-0,03)^{2}=0,62
\end{array}} \\
A_{5}=\sqrt{\begin{array}{c}
(0,11-0,03)^{2}+(0,08-0)^{2}+(0,05-0)^{2}+(0,07-0)^{2} \\
+(0,02-0,03)^{2}+(0,01-0,06)^{2}=0,62
\end{array}} \\
A_{1}=\sqrt{\begin{array}{c}
(0,03-0)^{2}+(0,08-0)^{2}+(0,05-0)^{2}+(0,02-0)^{2} \\
+(0,02-0,02)^{2}+(0,03-0)^{2}=0,46
\end{array}} \\
A_{2}=\sqrt{\begin{array}{c}
(0,08-0)^{2}+(0,03-0)^{2}+(0,02-0,05)^{2}+(0-0)^{2} \\
+(0,03-0,02)^{2}+(0,01-0)^{2}=0,42
\end{array}} \\
A_{3}=\sqrt{\begin{array}{c}
(0,08-0)^{2}+(0,08-0)^{2}+(0,04-0)^{2}+(0-0)^{2} \\
+(0,02-0,02)^{2}+(0,01-0)^{2}=0,47
\end{array}} \\
A_{4}=\sqrt{\begin{array}{c}
(0,05-0)^{2}+(0,03-0)^{2}+(0,01-0)^{2}+(0,02-0)^{2} \\
+(0,03-0,02)^{2}+(0,03-0)^{2}=0,40
\end{array}} \\
\sqrt{\begin{array}{c}
(0,03-0)^{2}+(0-0)^{2}+(0-0)^{2}+(0-0)^{2} \\
+(0,02-0,02)^{2}+(0,01-0)^{2}=0,40
\end{array}}
\end{array}
\end{aligned}
$$

Tabel 13. Matriks D+ (Solusi Ideal Positif) dan D- (Solusi Ideal Negatif)

\begin{tabular}{|l|l|l|l|l|l|}
\hline \multicolumn{1}{|c|}{ Alternatif } & \multicolumn{1}{c|}{$\mathrm{D}+$} & \multicolumn{1}{c|}{$\mathrm{D}-$} & \multicolumn{1}{c|}{ Alternatif } & $\mathrm{D}+$ & $\mathrm{D}-$ \\
\hline $\mathrm{A}_{1}$ & 0,61 & 0,46 & $\mathrm{~A}_{14}$ & 0,62 & 0,30 \\
\hline $\mathrm{A}_{2}$ & 0,61 & 0,42 & $\mathrm{~A}_{15}$ & 0,62 & 0,30 \\
\hline $\mathrm{A}_{3}$ & 0,61 & 0,47 & $\mathrm{~A}_{16}$ & 0,61 & 0,41 \\
\hline $\mathrm{A}_{4}$ & 0,62 & 0,40 & $\mathrm{~A}_{17}$ & 0,62 & 0,29 \\
\hline $\mathrm{A}_{5}$ & 0,62 & 0,24 & $\mathrm{~A}_{18}$ & 0,61 & 0,43 \\
\hline $\mathrm{A}_{6}$ & 0,61 & 0,49 & $\mathrm{~A}_{19}$ & 0,62 & 0,24 \\
\hline $\mathrm{A}_{7}$ & 0,62 & 0,35 & $\mathrm{~A}_{20}$ & 0,62 & 0,38 \\
\hline $\mathrm{A}_{8}$ & 0,60 & 0,56 & $\mathrm{~A}_{21}$ & 0,61 & 0,46 \\
\hline $\mathrm{A}_{9}$ & 0,61 & 0,45 & $\mathrm{~A}_{22}$ & 0,62 & 0,28 \\
\hline $\mathrm{A}_{10}$ & 0,62 & 0,38 & $\mathrm{~A}_{23}$ & 0,61 & 0,51 \\
\hline $\mathrm{A}_{11}$ & 0,61 & 0,51 & $\mathrm{~A}_{24}$ & 0,62 & 0,35 \\
\hline $\mathrm{A}_{12}$ & 0,62 & 0,26 & $\mathrm{~A}_{25}$ & 0,62 & 0,40 \\
\hline $\mathrm{A}_{13}$ & 0,60 & 0,50 & & & \\
\hline
\end{tabular}

Langkah terakhir dari perhitungan Topsis adalah menghitung nilai preferensi untuk alternatif $\left(V_{i}\right)$ untuk masing-masing penilaian dengan persamaan

$$
V_{\mathrm{i}} \frac{D_{\mathrm{i}}^{-}}{\left(D_{\mathrm{i}}^{+}+D_{\mathrm{i}}^{-}\right)}
$$

$$
A_{1}=\frac{0,46}{(0,61+0,46)}=0,43
$$




$$
\begin{aligned}
& A_{2}=\frac{0,42}{(0,61+0,42)}=0,41 \\
& A_{3}=\frac{0,47}{(0,61+0,47)}=0,44 \\
& A_{4}=\frac{0,40}{(0,62+0,40)}=0,39 \\
& A_{5}=\frac{0,24}{(0,62+0,24)}=0,28
\end{aligned}
$$

Tabel 14. Matriks $V_{i}$

\begin{tabular}{|l|l|l|l|l|l|}
\hline \multicolumn{1}{|c|}{ Alternatif } & \multicolumn{1}{c|}{ Nama } & \multicolumn{1}{c|}{ Vi } & \multicolumn{1}{c|}{ Alternatif } & \multicolumn{1}{c|}{ Nama } & \multicolumn{1}{c|}{ Vi } \\
\hline $\mathrm{A}_{1}$ & Rendi & 0,43 & $\mathrm{~A}_{14}$ & Itang & 0,33 \\
\hline $\mathrm{A}_{2}$ & Anwar & 0,41 & $\mathrm{~A}_{15}$ & Aceng & 0,33 \\
\hline $\mathrm{A}_{3}$ & Ipan & 0,44 & $\mathrm{~A}_{16}$ & Engkos & 0,40 \\
\hline $\mathrm{A}_{4}$ & Unang & 0,39 & $\mathrm{~A}_{17}$ & Iwan & 0,32 \\
\hline $\mathrm{A}_{5}$ & Deni & 0,28 & $\mathrm{~A}_{18}$ & Muslimin & 0,41 \\
\hline $\mathrm{A}_{6}$ & $\begin{array}{l}\text { Mustopa } \\
\text { Kamal }\end{array}$ & 0,45 & $\mathrm{~A}_{19}$ & Agus Epul & 0,28 \\
\hline $\mathrm{A}_{7}$ & Nunung & 0,36 & $\mathrm{~A}_{20}$ & Ade & 0,38 \\
\hline $\mathrm{A}_{8}$ & Ade Sutisna & 0,48 & $\mathrm{~A}_{21}$ & Jaja & 0,43 \\
\hline $\mathrm{A}_{9}$ & Agus & 0,42 & $\mathrm{~A}_{22}$ & Adang & 0,31 \\
\hline $\mathrm{A}_{10}$ & ljam & 0,38 & $\mathrm{~A}_{23}$ & Nano & 0,46 \\
\hline $\mathrm{A}_{11}$ & Rudi & 0,46 & $\mathrm{~A}_{24}$ & Atep & 0,36 \\
\hline $\mathrm{A}_{12}$ & Agung & 0,30 & $\mathrm{~A}_{25}$ & Dodi & 0,39 \\
\hline $\mathrm{A}_{13}$ & Ma,mun & 0,45 & & & \\
\hline
\end{tabular}

Hasil akhir perhitungan topsis berdasarkan tabel 14, menampilkan rangking perhitungan berdasarkan nilai tertinggi sampai nilai terendah dan menunjukan bahwa nilai tertinggi terdapat pada kode RTS $\mathrm{A}_{8}$.

Tabel 15. Perangkingan Diurutkan

\begin{tabular}{|l|l|l|l|}
\hline \multicolumn{1}{|c|}{ No } & Alternatif & \multicolumn{1}{|c|}{ Nama } & $\mathrm{V}_{\mathrm{i}}$ \\
\hline 1 & $\mathrm{~A}_{8}$ & Ade Sutisna & 0,48 \\
\hline 2 & $\mathrm{~A}_{11}$ & Rudi & 0,46 \\
\hline 3 & $\mathrm{~A}_{23}$ & Nano & 0,46 \\
\hline 4 & $\mathrm{~A}_{6}$ & Mustopa Kamal & 0,45 \\
\hline 5 & $\mathrm{~A}_{13}$ & Ma,mun & 0,45 \\
\hline 6 & $\mathrm{~A}_{3}$ & Ipan & 0,44 \\
\hline 7 & $\mathrm{~A}_{1}$ & Rendi & 0,43 \\
\hline 8 & $\mathrm{~A}_{21}$ & Jaja & 0,43 \\
\hline 9 & $\mathrm{~A}_{9}$ & Agus & 0,42 \\
\hline 10 & $\mathrm{~A}_{2}$ & Anwar & 0,41 \\
\hline 11 & $\mathrm{~A}_{18}$ & Muslimin & 0,41 \\
\hline 12 & $\mathrm{~A}_{16}$ & Engkos & 0,4 \\
\hline 13 & $\mathrm{~A}_{4}$ & Unang & 0,39 \\
\hline 14 & $\mathrm{~A}_{25}$ & Dodi & 0,39 \\
\hline 15 & $\mathrm{~A}_{10}$ & ljam & 0,38 \\
\hline 16 & $\mathrm{~A}_{20}$ & Ade & 0,38 \\
\hline 17 & $\mathrm{~A}_{7}$ & Nunung & 0,36 \\
\hline 18 & $\mathrm{~A}_{24}$ & Atep & 0,36 \\
\hline 19 & $\mathrm{~A}_{14}$ & Itang & 0,33 \\
\hline 20 & $\mathrm{~A}_{15}$ & Aceng & 0,33 \\
\hline 21 & $\mathrm{~A}_{17}$ & Iwan & 0,32 \\
\hline 22 & $\mathrm{~A}_{22}$ & Adang & 0,31 \\
\hline & & & \\
\hline
\end{tabular}




\begin{tabular}{|l|l|l|l|}
\hline 23 & $\mathrm{~A}_{12}$ & Agung & 0,3 \\
\hline 24 & $\mathrm{~A}_{5}$ & Deni & 0,28 \\
\hline 25 & $\mathrm{~A}_{19}$ & Agus Epul & 0,28 \\
\hline
\end{tabular}

Hasil akhir perhitungan topsis berdasarkan tabel 15 menampilkan rangking perhitungan yang telah diurutkan berdasarkan nilai tertinggi sampai terendah dan alternatif yang dipilih yaitu nilai tertinggi dari perhitungan dengan jumlahnya sesuai sama kuota yang telah ditentukan oleh pemerintah. Jika kuota KKS adalah 5 maka penerima KKS adalah 5 orang dengan nilai teratas, pada contoh kasus diatas 5 orang tersebut adalah Ade Sutisna,Rudi, Nano, Mustopa Kamal, Ma'mun.

\section{E. KESIMPULAN}

Berdasarkan pembahasan yang telah dipaparkan, metode TOPSIS dapat menghasilkan nilai kelayakan penerima Kartu Keluarga Sejahtera (KKS) secara objektif berdasarkan urutan nilai tertinggi. Penerapan sistem informasi penentuan penerima KKS membantu dalam menyeleksi keluarga calon penerima bantuan KKS secara objektif dan cepat. Output yang dihasilkan oleh sistem ini dapat dijadikan sebagai bahan pertimbangan dalam mengambil keputusan penerima Kartu Keluarga Sejahtera (KKS). Dengan adanya sistem pendukung keputusan ini, diharapkan program bantuan KKS tepat sasaran dan dapat menggulangi kemiskinan.

\section{REFERENSI}

Arifin, B. (2015). Sistem pendukung keputusan rekomendasi pemilihan mobil bekas dengan menggunakan metode TOPSIS. 151, 10-17. https://doi.org/10.1145/3132847.3132886

Hertyana, H. (2019). Seleksi Penerimaan Karyawan Baru Menggunakan Metode Topsis. Jitk, $4(2), 1-8$.

Hikmat, I. R. H. (2017). Pengelolaan Bantuan Sosial Program Keluarga Harapan Yang Lebih Berkualitas Disampaikan Pada Seminar Budget Day Persentase Angka Kemiskinan Indonesia 2015-2017. (November).

Nofriansyah, D. (2015). Konsep Data Mining Vs Sistem Pendukung Keputusan. Deepublish.

Siahaya, R. M., \& T. Arie Setiawan P, S.T., M. C. (2015). Perancangan Sistem Pendukung Keputusan Evaluasi Kinerja Guru dengan Menggunakan Metode Topsis ( Studi Kasus: SMA Kristen 1 Salatiga) Perancangan Sistem Pendukung Keputusan Evaluasi Kinerja Guru dengan Menggunakan Metode Topsis ( Studi Kasus : SMA Kriste. (672013701).

Suryadi, L. (2017). Pemodelan Sistem Penunjang Keputusan Rektrutmen Karyawan Dengan Metode TOPSIS (Technique For Order Preference By Similarity To Ideal Solution) Studi Kasus : PT . Bahtera Pesat Lintasbuana. 79-86.

Yuliawati, D. (2017). Sistem Pendukung Keputusan Penerima Kartu Keluarga Sejahtera (KKS) Menggunakan Metode Simple Additive Weighting (SAW). Jurnal Teknologi Informasi Magister, 1(02), 203-217. 